\title{
Financial Innovation, Economic Growth, and the Consequences of Macroprudential Policies
}

\author{
Maxence Luc-Bernier \\ Michael Plouffe \\ University College London \\ 24 November 2017
}

\begin{abstract}
We leverage a 'catch-all' measure of financial innovation - research and development spending in the financial sector - to assess the net relationship between financial innovation and economic growth and evaluate the influence of macroprudential policy on this relationship. Using a panel of 23 countries over the period of 1996-2014, our results demonstrate a net-positive relationship between financial innovation and gross capital formation. We find no evidence of a net-negative impact of financial innovation on economic growth, challenging the popular and political stigma surrounding financial innovation. We also find little robust evidence of macroprudential policy influencing the relationship between financial innovation and economic growth. Our results support a functional approach to the regulation of financial innovation, which improves the intermediation process, leading to increased capital formation.
\end{abstract}

\section{Highlights:}

- Financial-sector spending on research and development is used as a proxy for aggregate financial innovation.

- Financial innovation is positively related to economic growth through gross capital formation, but demonstrates no significant link with per capita GDP growth or new firm density.

- Macroprudential policy does not influence financial innovation's impact on capital formation, and its effect on financial innovation's relationship with other growth measures is specification dependent.

Keywords: Financial innovation, Macroprudential policy, Economic growth, Capital formation, Financial intermediation

JEL Classification Codes: E44, G01, G20, G28

We thank Lucy Barnes and Jack Blumenau for helpful comments. This research did not receive any specific grant from funding agencies in the public, commercial, or not-for-profit sectors. 


\section{Introduction}

The use of financial innovation has surged over the past decade (Segoviano, 2013). For instance, collaterized debt obligations, a type of financial innovation, grew from $\$ 20 \mathrm{bn}$ in 2004 to $\$ 1.8 \mathrm{~T}$ in 2007 (Barnett-Hart, 2009). Heralded as the cause of the Great Financial Crisis (2007-2008), financial innovation has became popularly perceived as risk-inducing instruments that with no positive impact on economic growth (Dwyer, 2011).

In response, policy-makers have increasingly relied on macroprudential policy tools to limit systemic risk induced by financial innovation (Calomiris, 2009). Surprisingly, there remains a lack of consensus on both 1) the impact of financial innovation on economic growth, and 2) whether macroprudential policies improve or worsen the economic effects of financial innovation (Bertay et al., 2017; Beck et al., 2016). Financial innovation is a field of substantial growth, high scrutiny, and increasing regulation, yet with no academic agreement on either its macroeconomic effects or the proper policy approach.

This study examines two key questions:

1. What is the net effect of financial innovation on economic growth?

2. Do different macroprudential policy eco-systems improve or worsen the effect of financial innovation on economic growth?

Leveraging panel data of 23 economies between 1996 to 2014, we use a novel proxy for financial innovation - research and development spending in the financial sector (ANBERD) - and a novel index of macroprudential policy (Cerruti et al., 2015). Our results are robust, demonstrating that:

1. Financial innovation is positively associated with one of the measures of economic growth - capital formation;

2. Macroprudential policies neither worsen nor improve the effect of financial innovation on economic growth.

\section{Capturing financial innovation}

Financial innovation is a unique type of innovation. Unlike manufacturing or pharmaceutical innovation, it does not rely on patents, nor does it have a similar cost structure (Tufano, 2002). Financial innovation originates from financial institutions whose purpose is principally one of intermediation: connecting savers and investors-spenders. Savers have excess capital they wish to both safeguard and gain interest on while, investors-spenders seek capital resources. Financial institutions, serving as intermediaries, are constantly evaluating both savers and investors. Their objective is to efficiently allocate the resources of savers to investors-spenders that will return the 
capital with interest and without default (Frame and White, 2002). Financial intermediation is thus a process characterized by information asymmetries, moral hazard, and incentive problems (Galati and Moessner, 2012), and consists of any process, product or service which improves the intermediation function either through improved screening, risk analysis, or capital and riskmatching.

The importance of finance and innovation on economic growth have long been established. The role of the financial sector in economic growth, regardless of whether it serves a supply or a demand-function, is deemed necessary for economic performance (Levine, 1997; King and Levine, 1993). In parallel, technological innovation is also recognized as a key driver of economic growth (Marquez-Ramos and Martinez-Zarzoso, 2010; Fagerberg, 1997; Posner, 1961). Consequently, financial innovation, which encompasses two key drivers of economic growth, finance and innovation, should be an area of high research interest. However, to date research on the economic impact of financial innovation remain negligible at best (Beck et al., 2016).

On top of scant extant research, financial innovation suffers from two opposing views on its economic impact. The innovation-growth view, on the one hand, posits that financial innovation optimizes the process of financial intermediation and in turn stimulates economic growth. The innovation-fragility view, on the other hand, stipulates that financial innovation leads to a more fragile and vulnerable financial system, thus impeding economic growth (Beck et al., 2016). There is no consensus on which view is dominant.

Moreover, the diversity of financial innovations impedes their study, while their consequences are often manifested as externalities. Consequently, most research has solely examined specific innovations (Lerner and Tufano, 2011). To overcome this challenge, we leverage a novel proxy of financial innovation: research and development spending in the financial sector (from now referred to as "R\&D spending"). While this is a departure from the prevailing focus on more specific innovations themselves, it allows us to assess the net effect of financial innovations on economic growth.

\subsection{Regulation-induced financial innovation and macroprudential policy}

In response to the systemic risks imposed by the financial sector on the real economy, and the ensuing anti-innovation sentiment, policy-makers have increasingly relied on macroprudential policies (Basto, 2013). These policy tools, mainly in the form of reserve requirements and leverage ratios, are put in place to prevent financial risks spreading to the real economy. However, financial innovation is mainly driven by regulatory reform (Miller, 1986). As Shan et al. (2016) put it, the economic effects of 'regulation-induced financial innovation' have sometimes 
been positive and sometimes negative (Wall, 2014; Yorulmazer, 2012). Therefore, what remains unknown is the impact of these macroprudential policies on financial innovation. To date, there is no empirical evidence informing policy-makers of the impact of macroprudential policies on financial innovation, specifically, whether they improve, or worsen, their effect on economic growth.

\section{Effects of financial innovation}

The earliest support for financial innovation stems from Schumpeter $(1950,1911)$, through his depiction of the process of creative destruction, as well as his emphasis on the importance of financial development for economic growth. He argues that financial intermediaries serve a critical role in the economy by efficiently allocating savings to entrepreneurs, enabling both technological innovation and economic development (Schumpeter 1911; King and Levine, 1993).

This framework continues to guide researchers studying the impact on innovation. Laeven et al. (2015), for example, demonstrate the role of financial innovation in fostering technical innovation, and consequently, economic growth. Tufano (2002) empirically demonstrates the former link as well. Financial innovation also reduces the moral hazard associated with capital allocation. Modelling for improved monitoring efficiency, a form of financial innovation, Morales (2003) finds that increased monitoring intensity on entrepreneurs results in a higher probability of success, translating into greater economic growth. Improving financial intermediation, through financial innovation, is therefore perceived as having a positive impact on the economy by increasing the productivity of entrepreneurial activity. Financial innovation also improves the effectiveness of allocating savings capital to investment capital. Chou (2007) assesses the efficiency of financial intermediation, finding a robust role in innovation in improving the intermediation process.

Finally, financial innovation enhances liquidity in markets. In a note published by the IMF (Segoviano et al., 2015), securitization is argued to positively contribute to the economy by rendering a pool of illiquid assets into tradable securities, increasing available capital and enabling risk diversification. However, securitization has not always contributed to economic growth, notably during the Great Financial Crisis (2007-2008), when it effectively magnified problems with loan origination (Keys et al., 2016), highlighting the need for an appropriate ecosystem of regulations and policy to avoid incentive misalignment (Barnett-Hart, 2009). 
While theoretical research on financial innovation primarily identifies positive consequences, demonstrating its role in reducing moral hazard, improving intermediation, and increasing liquidity in the market, empirical research, primarily conducted via case study, presents a mixed bag (Janicko, 2015). In the following sections, we review evidence for the effects of venture capital and securitization, which have frequently been used as proxies for financial innovation.

\subsection{Venture capital}

Venture capital (VC) is an example of financial innovation that emerged in the 1950s, stemming from the information asymmetries and moral hazard present in financial intermediation. VC firms thus arose with innovative processes such as convertible securities, syndication and staging of investments, and oversight procedures to improve this process (Lerner and Tufano, 2011).

The impact of VC on macroeconomic performance has been significant and indisputably positive. For example, in 2008, VC-funded firms represented 13\% of all public companies in the United States, amounting to $\$ 2.4$ trillion (US), or $8.4 \%$ of total market value. In the technology sector alone, VC-funded firms make up $75 \%$ of all public firms, highlighting the link between $\mathrm{VC}$ and technological innovation. The positive effects of $\mathrm{VC}$ have been linked to a wide range of real economic outcomes (Samila and Sorenson, 2011), particularly through knowledge transfers, cumulating in economic growth (Urbano and Aparicio, 2016).

\subsection{Securitization}

Securitized products generally consist of debt obligations, issued either to household or businesses, which are packaged together and sold as a single instrument for risk dispersion, which often leads to their use as a proxy for financial innovation (Janicko, 2015). Securitization represents a highly efficient intermediation product between savers and borrowers, resulting in a decreased cost of capital (Calbo-Valverde, 2015; Nadauld and Weisbach, 2012), and facilitating household access to credit (Lerner and Tufano, 2011). However, the extent to which these welfare gains translate into positive macroeconomic effects is unclear. For instance, increases in credit supply can predict banking crises (Büyikkarabacak and Valev, 2010) and have negative impacts on banks' financial sounding (Michalak and Uhde, 2012).

Bertay et al. (2016) examine the impact of securitization on economic growth through three indicators of economic performance: GDP per capita growth, new firm density formation, and capital formation. Securitization of household and enterprise debts have different impacts on growth, with household securitization negatively linked to economic outcomes, and enterprise securitization exerting a positive effect. The mechanism underlying this relationship is thought to be due to the investment to consumption ratio. Given that household securitization comprises 
of a more homogenous pool of debts, as compared to enterprises, the process of household loans is thus theorized to be streamlined as compared to enterprises loans. Consequently, increased demand for household securitization increases the cost of capital for enterprises, thereby decreasing the investment to consumption ratio. The ensuing situation is one none too different from what led to the Great Financial Crisis. These results suggest that financial innovations which favour consumption over investment are likely to have a negative effect on the economy; while those that favour investment over consumption will have a positive effect on the economy.

\section{Regulation-induced financial innovation and macroprudential policy}

As first highlighted by Miller (1986), financial innovation is mainly driven by regulatory reform. Such innovations often arise with the sole objective of exploiting regulatory gaps, prompting new regulations which, in turn, prompt further innovations (Ross, 2016). In line with the two contrasting views of financial innovation - the innovation-growth and innovation-fragility view regulation-induced financial innovation can produce both positive and negative effects on the economy. The academic literature on regulation-induced financial innovation is inconclusive with respect to the impact on economic growth. Regulation, if ill-conceived, can result in innovation that ultimately decreases economic stability and impedes growth (Lumpkin, 2009), although it has also been shown to drive growth-enhancing innovation (Silber, 1983).

On the other hand, financial innovations have been employed to circumvent macroprudential policy tools such as capital and reserve requirements. Yorulmazer (2012) and Shan et al. (2016) demonstrate how capital requirements can entice financial institutions to utilize credit default swaps (CDSs) to transfer risk-weighted assets from the balance sheet, but without necessarily reducing risk. Robitaille (2011) comes to similar conclusions, showing that reserve requirements were purposely avoided using financial innovation in Brazil. This avoidance of macroprudential policies could be significantly harmful to economic performance as these policies prevent against systemic risk (IMF, 2011; Gauthier et al., 2010).

Consequently, while financial development and innovation has long been positively associated with real economic growth, regulation-induced innovations can erode this relationship. The functional driver of innovations fundamentally influences their influence on the wider economy: where they are directed at enterprise growth and investment, this impact is positive, while this is not the case for innovations driven by consumer spending. 


\section{Financial Innovation, Macroprudential Policies, and Economic Growth}

While much research has focused on the regulatory drivers of financial innovation or on the consequences of specific forms of innovation, little work has sought to uncover the aggregate effects of financial innovation (Beck et al., 2016 is a notable exception). We assess the effects of an aggregate measure of financial innovation - financial-sector research and development expenditures - on three measurements of economic growth: per capita GDP growth, new firm density, and gross capital formation.

While we expect a positive relationship between financial innovation and each growth measure, this should be particularly strong with respect to capital formation, as a result of the functional roles of financial innovations in improving intermediation processes as well as promoting enterprise growth and investment. While obviously our catchall measure also captures consumeroriented measures, such as those aimed at increasing consumer spending, as well as potentially growth-impeding innovations spurred by regulatory avoidance, we expect the beneficial aspects of financial innovation to outweigh these negative attributes in terms of their implications for economic growth.

Given the role played by the regulatory environment in shaping the motivations behind financial innovation, we expect macroprudential policy to influence the net relationship between financial innovation and economic growth. Environments that are experiencing high levels of macroprudential-policy use are likely to see financial innovation aimed at reducing or avoiding regulatory burdens, as financial institutions innovate to purposely avoid the functional objectives of regulations (Calomiris, 2009). Those with no or minimal macroprudential measures will see financial innovation more closely aligned with the innovation's issuer and consumer. Consequently, macroprudential policy should negatively influence the relationship between financial innovation and economic growth.

\section{Data and Methodology}

We first examine the impact of financial innovation on economic growth using $\mathrm{R} \& \mathrm{D}$ expenditures in the financial services sector from the Analytical Business Enterprise Research and Development database (ANBERD) as our broad measure of financial innovation (following Beck et al., 2016). We then examine the interactive effects of macroprudential policy with financial innovation on economic growth, using the macroprudential-policy index developed by 
Cerutti et al. (2015). Our dataset is an unbalanced panel of 23 countries, spanning 1996-2014. ${ }^{1}$ Table A1, in the appendix, presents the list of variables employed in our analysis, along with their sources, while Table 1 presents descriptive statistics.

Table 1. Cross-country summary statistics.

\begin{tabular}{lccccc}
\hline & \# of Obs. & Mean & Std. Dev. & Min & Max \\
\hline GDP per capita growth & 322 & 2.008 & 3.268 & -14.724 & 15.240 \\
Capital formation & 323 & 23.306 & 4.131 & 14.632 & 47.584 \\
New firm density & 188 & 3.542 & 2.685 & 0.150 & 12.900 \\
R\&D spending & 294 & 0.254 & 0.345 & 0.001 & 1.956 \\
Macroprudential policy & 182 & 2.049 & 1.058 & 0 & 5 \\
Banking crises & 323 & 0.204 & 0.404 & 0 & 1 \\
Urbanization & 284 & 25.667 & 20.474 & 5.603 & 100.000 \\
Education & 270 & 0.992 & 0.036 & 0.798 & 1.066 \\
Government expenditure & 294 & 18.691 & 3.881 & 8.906 & 28.064 \\
Inflation & 294 & 4.138 & 11.042 & -5.205 & 137.965 \\
Trade/GDP & 294 & 95.068 & 77.539 & 20.258 & 439.657 \\
Domestic credit to private sector & 273 & 122.820 & 74.205 & 4.345 & 366.533 \\
Stocks traded/GDP & 267 & 56.193 & 54.695 & 0.865 & 320.992 \\
\hline
\end{tabular}

Our baseline specification employs country and year fixed effects to capture unobserved heterogeneity. We rely on within-country variation to demonstrate the relationship between financial innovation and economic growth. All of our explanatory variables are lagged by one year.

\subsection{Measuring Economic Growth}

To capture economic performance, we rely on three common indicators from the financialdevelopment literature: per capita GDP growth, capital formation, and new firm density. Per capita GDP growth, often used as the main indicator of economic growth, cannot independently capture all economic fluctuations seen with economic growth. Capital formation and new firm density efficiently complement this first measure by identifying supply-side factors of economic growth (Bertay et al. 2017).

\subsection{Explanatory Variables}

Our inclusive approach to capturing financial innovation contrasts with most previous work, incorporating financial-sector R\&D expenditures from ANBERD, following Beck et al. (2016), who establish its validity and reliability as a proxy measure for financial innovation. Cerutti et al.'s (2015) macroprudential policy index is based on a number of regulatory policies, including loanto-value ratio, debt-to-income ratio, limits on foreign- and domestic-currency loans, and leverage ratios.

\footnotetext{
1 The countries are Australia, Austria, Belgium, Canada, the Czech Republic, Denmark, Estonia, Finland, France, Germany, Ireland, Israel, Italy, Japan, Mexico, the Netherlands, Norway, Singapore, Slovenia, Sweden, Turkey, the United Kingdom, and the United States.
} 
We complement these two measures with a battery of controls consistently used in the financialdevelopment literature. Domestic credit and stock market development capture any direct effect that credit availability might have on economic growth. Inflation rates and trade-GDP ratio control for macroeconomic stability and economic openness, respectively. We include government expenditures (operationalized as government final consumption as a share of GDP), and education and urbanization rates to paint a broader picture of the macroeconomy. Finally, we use a banking-crisis indicator from Laeven and Valencia (2015).

\subsection{Financial Innovation and Economic Growth}

Our first aim is to determine whether R\&D spending in the financial sector - our proxy for financial innovation - is associated with economic growth. Table 2 presents results for tests using our three growth proxies. Interestingly, R\&D spending is neither associated with per capita GDP growth, nor new firm density (Models 1 and 2), although it is positively linked to capital formation (Model 3). In Model 1, only domestic credit to the private sector exhibits a relationship with per capita GDP growth, which can be explained by the fact that credit bubbles have been shown to predict banking crises and economic contraction (Arcand et al., 2015; Beck et al., 2016; Bertay et al., 2016; Büyuikkarabacak and Valev, 2010).

In Model 2, only education and government expenditures are significant. While education is positively linked to new firm density, government expenditure is negatively associated with the outcome, replicating Bertay et al.'s (2016) results. This effect is likely capturing a public-sector economy bias, whereby governments with higher expenditures are likely to represent those with larger welfare states and public-sector economies. The lack of relationship between R\&D spending and new firm density contrasts with that of Samila and Sorenson (2011), who find that venture-capital funding is positively linked with new firm density. However, while venture capital is typically directed at entrepreneurial activity, $\mathrm{R} \& \mathrm{D}$ spending is a broader measure of innovation. Likewise, R\&D activities are often undertaken by established firms rather than new market entrants.

Finally, R\&D spending is positively and significantly associated with gross capital formation, as demonstrated in Model 3. Most of the controls that gain significance have the expected effect on gross capital formation: urbanization is positively linked, while banking crises and private credit reduce capital formation. The notable exception is trade openness, which is negatively related to capital formation, running counter to a result in a similar model in Bertay et al. (2016). 
Table 2. R\&D spending and economic growth.

\begin{tabular}{lccc}
\hline & Model 1 & Model 2 & Model 3 \\
\hline R\&D spending & $\begin{array}{c}\text { Per capita GDP } \\
\text { growth }\end{array}$ & $\begin{array}{c}\text { New firm density } \\
\text { growth }\end{array}$ & $\begin{array}{c}\text { Gross capital } \\
\text { formation }\end{array}$ \\
Banking crises & 0.200 & -0.122 & $2.072^{*}$ \\
& $(0.974)$ & $(0.356)$ & $(0.821)$ \\
Education & -0.361 & 0.014 & $-0.949^{*}$ \\
& $(0.555)$ & $(0.173)$ & $(0.473)$ \\
Urbanization & 1.147 & $16.422^{*}$ & 0.885 \\
& $(7.744)$ & $(7.588)$ & $(11.189)$ \\
Government expenditure & -0.133 & -0.341 & $0.708^{*}$ \\
& $(0.184)$ & $(0.215)$ & $(0.283)$ \\
Inflation & 0.165 & $-0.527^{* * *}$ & -0.172 \\
& $(0.265)$ & $(0.090)$ & $(0.279)$ \\
Trade over GDP & -0.026 & 0.097 & 0.041 \\
& $(0.024)$ & $(0.062)$ & $(0.030)$ \\
Domestic credit to private sector & -0.020 & 0.012 & $-0.106^{* * *}$ \\
Stocks traded over GDP & $(0.024)$ & $(0.022)$ & $(0.018)$ \\
Number of observations & $-0.028^{*}$ & -0.008 & $-0.037^{* *}$ \\
$\mathrm{R}^{2}$ & $(0.012)$ & $(0.004)$ & $(0.013)$ \\
Adjusted R & -0.001 & -0.005 & -0.004 \\
Number of countries & $(0.006)$ & $(0.003)$ & $(0.007)$ \\
\hline Note. & 213 & 132 & 214 \\
\end{tabular}

Note. ${ }^{* *} \mathrm{p}<0.01,{ }^{* *} \mathrm{p}<0.05,{ }^{*} \mathrm{p}<0.1$. Linear model with country and year FE. Standard errors in parentheses are clustered at the country level.

Consequently, we find partial support for the relationship between $R \& D$ expenditures and economic growth in Table 2's models. While financial sector R\&D spending has not effect on per capita GDP growth or new firm density, it is positively linked to gross capital formation.

The next step in our analysis is to analyze the interaction between $R \& D$ spending and macroprudential policy and the consequent effects on economic growth. Table 3 presents results for these models, which are otherwise comparable to those in the previous table. The relationship between $\mathrm{R} \& \mathrm{D}$ spending and growth is comparable to that in the preceding models. The interaction effect is only significantly linked to gross capital formation, possessing a negative sign. This suggests that higher levels of macroprudential policy weaken the positive impact of financial innovation on capital formation. 
Table 3. Macroprudential policy index, R\&D spending, and economic growth.

\begin{tabular}{|c|c|c|c|}
\hline & Model 4 & Model 5 & Model 6 \\
\hline & $\begin{array}{l}\text { GDP per capita } \\
\text { growth }\end{array}$ & $\begin{array}{l}\text { New firm density } \\
\text { growth }\end{array}$ & $\begin{array}{c}\text { Gross capital } \\
\text { formation }\end{array}$ \\
\hline R\&D spending & $\begin{array}{c}0.688 \\
(1.396)\end{array}$ & $\begin{array}{l}-0.244 \\
(0.524)\end{array}$ & $\begin{array}{c}2.680^{* *} \\
(0.817)\end{array}$ \\
\hline R\&D x Macroprudential policy & $\begin{array}{l}-0.939 \\
(0.565)\end{array}$ & $\begin{array}{c}0.174 \\
(0.530)\end{array}$ & $\begin{array}{l}-1.536^{*} \\
(0.673)\end{array}$ \\
\hline Macroprudential policy index & $\begin{array}{c}0.306 \\
(0.187)\end{array}$ & $\begin{array}{l}-0.064 \\
(0.119)\end{array}$ & $\begin{array}{c}0.467 \\
(0.265)\end{array}$ \\
\hline Banking crises & $\begin{array}{l}-0.598 \\
(0.603)\end{array}$ & $\begin{array}{c}0.049 \\
(0.222)\end{array}$ & $\begin{array}{c}-1.291 * * \\
(0.467)\end{array}$ \\
\hline Education & $\begin{array}{c}1.843 \\
(10.737)\end{array}$ & $\begin{array}{l}17.273 \\
(8.955)\end{array}$ & $\begin{array}{c}0.121 \\
(11.477)\end{array}$ \\
\hline Urbanization & $\begin{array}{l}-0.163 \\
(0.240)\end{array}$ & $\begin{array}{l}-0.344 \\
(0.223)\end{array}$ & $\begin{array}{c}0.742^{* *} \\
(0.265)\end{array}$ \\
\hline Government expenditure & $\begin{array}{c}0.204 \\
(0.314)\end{array}$ & $\begin{array}{c}-0.538^{* * *} \\
(0.104)\end{array}$ & $\begin{array}{l}-0.268 \\
(0.288)\end{array}$ \\
\hline Inflation & $\begin{array}{c}0.001 \\
(0.036)\end{array}$ & $\begin{array}{c}0.096 \\
(0.061)\end{array}$ & $\begin{array}{l}0.065 \\
(0.046)\end{array}$ \\
\hline Trade over GDP & $\begin{array}{l}-0.016 \\
(0.042)\end{array}$ & $\begin{array}{c}0.012 \\
(0.023)\end{array}$ & $\begin{array}{c}-0.093 * * * \\
(0.020)\end{array}$ \\
\hline Domestic credit to private sector & $\begin{array}{l}-0.025 \\
(0.013)\end{array}$ & $\begin{array}{l}-0.008 \\
(0.004)\end{array}$ & $\begin{array}{c}-0.037 * * \\
(0.012)\end{array}$ \\
\hline Stocks traded over GDP & $\begin{array}{l}-0.003 \\
(0.006)\end{array}$ & $\begin{array}{l}-0.005 \\
(0.003)\end{array}$ & $\begin{array}{l}-0.008 \\
(0.005)\end{array}$ \\
\hline Number of observations & 191 & 132 & 192 \\
\hline $\mathrm{R}^{2}$ & 0.139 & 0.374 & 0.423 \\
\hline Adjusted $\mathrm{R}^{2}$ & 0.099 & 0.226 & 0.300 \\
\hline Number of countries & 21 & 20 & 21 \\
\hline
\end{tabular}

Figure 1 illustrates the effects of this interaction. Examining the interaction effect disaggregated by each level of the macroeconomic policy index highlights the potential influence of a single data point: Portugal in 2013. During this time, Portugal was struggling to cope with unique economic hardship. The financial crisis had put a substantial strain on public finances, forcing the government to request a $\AA^{70 b n}$ bailout from the IMF and European Union (BBC, 2016). The bailout package was accompanied by stringent austerity measures. Additionally, the Portuguese government also had €9.6bn in outstanding bonds due in 2013 that it had to convert to a 2015 maturity following a reduction in the sovereign credit rating to below investment grade (Lima, 2013). This unique amalgamation of circumstances results in the combination of high levels of $\mathrm{R} \& \mathrm{D}$ spending and poor economic performance. Consequently, we remove this observation from the analysis. 
Figure 1. R\&D spending and capital formation as a function of macroprudential policy.

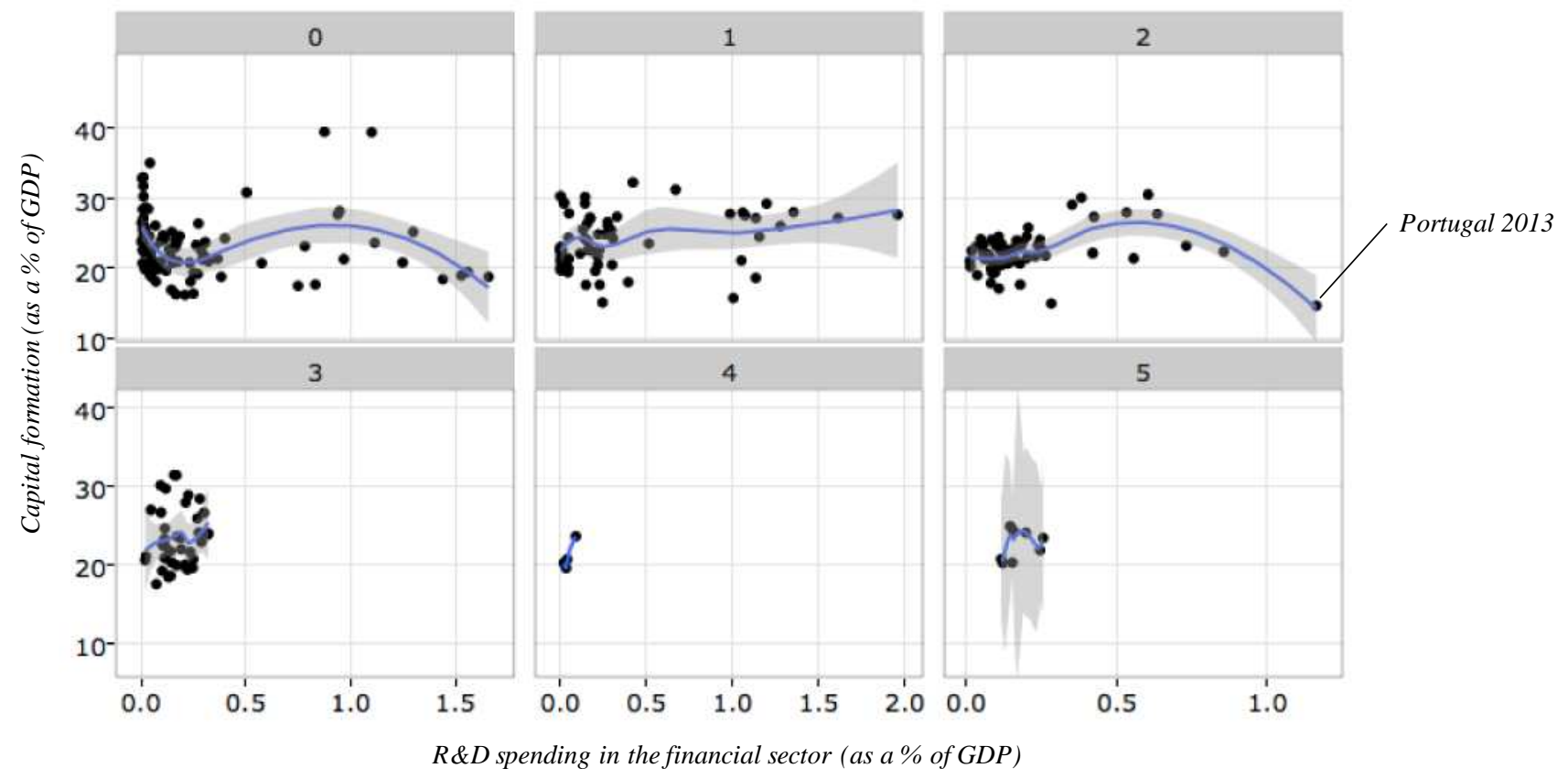

Note. The solid line shows the loess curve with SE at .95 CI.

The replications of Table 3 excluding the outlying observation are presented in Table 4 . The results in Models 7 and 8 are comparable to those in Models 4 and 5: there is no discernable effect of macroprudential policies on per capita GDP growth or growth in new firm density, while its interaction with $\mathrm{R} \& \mathrm{D}$ spending is also unrelated to these measures of economic performance. The independent effect of R\&D spending on both outcomes is also insignificant, again mirroring the previous results. The picture changes somewhat in Model 9, when gross capital formation is used as the indicator of economic performance. $R \& D$ spending maintains its independent positive effect on gross capital formation, while macroprudential policy remains insignificant. Omitting Portugal 2013 causes the interaction between the two to lose significance. The influence of the additional covariates on gross capital formation is comparable to the results displayed in Model 6, with the exception of the banking crisis indicator, which, like the interaction term, loses significance.

We graphically present the effects of the interaction between the macroprudential policy index and $R \& D$ spending for Model 9 in Figure 2. Without the outlying observation, the use of macroprudential policy no longer influences the relationship between R\&D spending and gross capital formation, perhaps made most clear when comparing the shape of the loess curve where the macroprudential policy index takes a value of two between Figures 1 and 2. Without Portugal 
2013, the curve flattens significantly, so that the differentiation of the effects on gross capital formation between high and low levels of R\&D spending disappears.

Table 4. Macroprudential policy index, R\&D spending, and the real economy. Portugal 2013 removed.

\begin{tabular}{|c|c|c|c|}
\hline & Model 7 & Model 8 & Model 9 \\
\hline & $\begin{array}{l}\text { GDP per capita } \\
\text { growth }\end{array}$ & $\begin{array}{l}\text { New firm density } \\
\text { growth }\end{array}$ & $\begin{array}{c}\text { Gross capital } \\
\text { formation }\end{array}$ \\
\hline \multirow[t]{2}{*}{ R\&D spending } & 1.789 & -0.244 & $1.872^{* *}$ \\
\hline & $(1.139)$ & $(0.524)$ & $(0.669)$ \\
\hline \multirow[t]{2}{*}{ R\&D x Macroprudential policy } & -1.717 & 0.174 & -0.266 \\
\hline & $(0.998)$ & $(0.520)$ & $(1.024)$ \\
\hline \multirow[t]{2}{*}{ Macroprudential policy index } & 0.306 & -0.064 & 0.387 \\
\hline & $(0.175)$ & $(0.119)$ & $(0.254)$ \\
\hline \multirow[t]{2}{*}{ Banking crises } & -0.455 & 0.049 & -0.873 \\
\hline & $(0.645)$ & $(0.222)$ & $(0.517)$ \\
\hline \multirow[t]{2}{*}{ Education } & 3.807 & 17.273 & 0.182 \\
\hline & $(10.474)$ & $(8.955)$ & $(11.580)$ \\
\hline \multirow[t]{2}{*}{ Urbanization } & -0.114 & -0.344 & $0.577^{*}$ \\
\hline & $(0.219)$ & $(0.223)$ & $(0.268)$ \\
\hline \multirow[t]{2}{*}{ Government expenditure } & 0.221 & $-0.538^{* * *}$ & -0.384 \\
\hline & $(0.277)$ & $(0.104)$ & $(0.264)$ \\
\hline \multirow[t]{2}{*}{ Inflation } & 0.006 & 0.096 & 0.035 \\
\hline & $(0.040)$ & $(0.061)$ & $(0.038)$ \\
\hline \multirow[t]{2}{*}{ Trade over GDP } & -0.033 & 0.012 & $-0.119^{* * *}$ \\
\hline & $(0.028)$ & $(0.023)$ & $(0.021)$ \\
\hline \multirow[t]{2}{*}{ Domestic credit to private sector } & $-0.026^{*}$ & -0.008 & $-0.038^{* *}$ \\
\hline & $(0.012)$ & $(0.004)$ & $(0.012)$ \\
\hline \multirow[t]{2}{*}{ Stocks traded over GDP } & -0.002 & -0.005 & -0.008 \\
\hline & $(0.005)$ & $(0.003)$ & $(0.005)$ \\
\hline Number of observations & 196 & 132 & 197 \\
\hline $\mathrm{R}^{2}$ & 0.094 & 0.366 & 0.365 \\
\hline Adjusted $\mathrm{R}^{2}$ & 0.072 & 0.252 & 0.280 \\
\hline Number of countries & 21 & 20 & 21 \\
\hline
\end{tabular}

Taken as a whole, these results point to a link between R\&D spending and economic growth through gross capital formation, but not through other economic-performance indicators. Macroprudential policy itself has no influence on these growth measures, nor does it appear to have any influence on the relationship between $R \& D$ spending and these economic outcomes.

For robustness, we also assess these models using a GEE approach. ${ }^{2}$ The structures of the correlation matrices vary across our economic-growth proxies, and QIC specification tests are presented in the appendix. ${ }^{3}$ The results for these models are largely consistent with those discussed above, and are presented in Table 5. Models 10-12, which replicate those presented in Table 3, produce substantively similar results. Financial R\&D spending is only linked to gross

\footnotetext{
2 The relatively narrow panel structure of the dataset precludes the successful application of the commonly used Blundell-Bond GMM estimator.

${ }^{3}$ In the appendix, QIC test results are presented for all possible correlation-matrix choices, while the first column of each selected matrix is presented below the related model results.
} 
capital formation, and while macroprudential policy itself has no independent effect on the growth proxies, its interaction with $\mathrm{R} \& \mathrm{D}$ spending reduces the latter's effect on gross capital formation.

Figure 2. R\&D spending in the financial sector and capital formation, as a function of macroprudential policy index. Portugal 2013 removed.

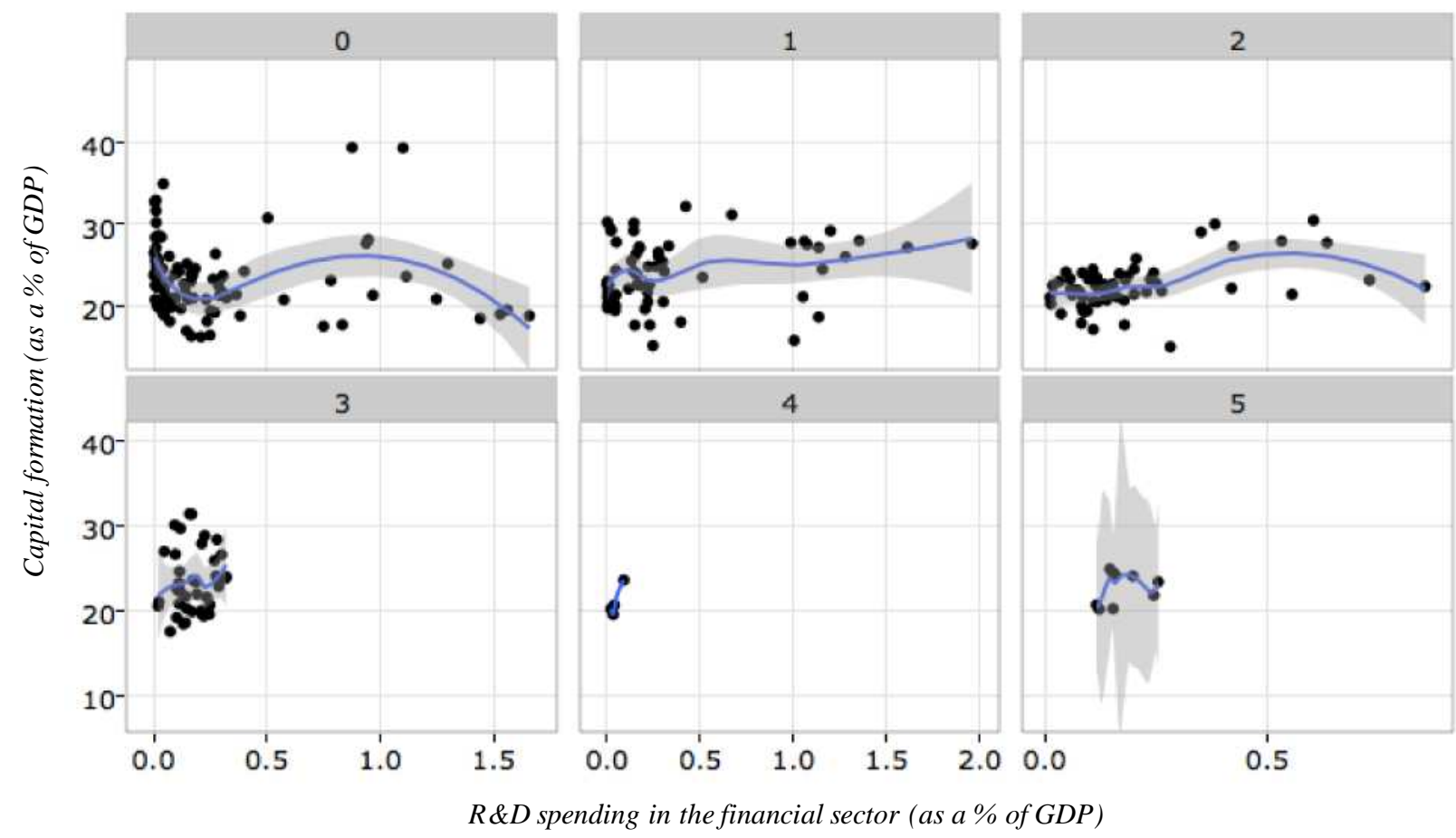

Note. The solid line shows the loess curve with SE at .95 CI.

Models 13-15 replicate those from Table 4, which exclude the outlying Portugal 2013 observation. Models 14 and 15 present comparable results to their Table 4 analogues, with R\&D spending positively linked to gross capital formation, and no significant impact of macroprudential policy or its interactive effect. Model 13 differs, however, in that the macroprudential policy is positively and significantly linked with per capita GDP growth, while its interaction with $\mathrm{R} \& \mathrm{D}$ spending is negatively associated with the growth proxy. The effects of the other covariates in these models are broadly consistent with those presented before.

To further test the robustness of the influences of $R \& D$ spending and its interaction with macroprudential policy on growth, we run a number of additional tests, with results presented in the appendix, but discussed in brief here. First, we remove the crisis indicator, as the presence of this term may be obscuring the independent effect of macroprudential policy on the growth proxies. This is not the case: in both GEE models (Table A10; QIC tests are presented in Tables A7-A9) and two-way FE models (Table A11), the macroprudential policy index does not gain significance. R\&D spending exhibits the same patterns as it does elsewhere: a positive and 
significant effect on gross capital formation, but no significant relationship with per capita GDP growth or new firm density. The interaction between $R \& D$ and macroprudential policy is negatively and significantly linked to per capita GDP growth, although this is model-dependent when Portugal 2013 is included in the analysis. It exhibits the same effect on capital formation as in previous tests: the significance of the negative relationship with gross capital formation disappears when Portugal 2013 is omitted.

Table 5. GEE estimates

\begin{tabular}{|c|c|c|c|c|c|c|}
\hline & Model 10 & Model 11 & Model 12 & Model 13 & Model 14 & Model 15 \\
\hline & GDP & Firms & Capital & GDP & Firms & Capital \\
\hline & \multicolumn{3}{|c|}{ All observations } & \multicolumn{3}{|c|}{ Portugal 2013 excluded } \\
\hline Correlation Matrix & Exchangeable + & Independent & $\mathrm{AR}(1)$ & Exchangeable+ & Independent & $\mathrm{AR}(1)$ \\
\hline R\&D spending & $\begin{array}{c}0.688 \\
(1.430)\end{array}$ & $\begin{array}{l}-0.244 \\
(0.538)\end{array}$ & $\begin{array}{c}2.090^{* * *} \\
(0.641)\end{array}$ & $\begin{array}{c}1.532 \\
(1.357)\end{array}$ & $\begin{array}{l}-0.244 \\
(0.538)\end{array}$ & $\begin{array}{c}1.614^{* * *} \\
(0.571)\end{array}$ \\
\hline \multirow{2}{*}{$\begin{array}{l}\text { R\&D x Macroprudential } \\
\text { policy }\end{array}$} & -0.939 & 0.174 & $-0.970 *$ & $-2.089 * *$ & 0.174 & -0.298 \\
\hline & $(0.579)$ & $(0.533)$ & $(0.555)$ & $(0.991)$ & $(0.533)$ & $(0.854)$ \\
\hline \multirow[t]{2}{*}{ Macroprudential policy } & 0.306 & -0.064 & 0.415 & $0.364 *$ & -0.064 & 0.390 \\
\hline & $(0.192)$ & $(0.122)$ & $(0.268)$ & $(0.206)$ & $(0.122)$ & $(0.270)$ \\
\hline \multirow[t]{2}{*}{ Banking crises } & -0.598 & 0.049 & -0.583 & -0.676 & 0.049 & -0.585 \\
\hline & $(0.618)$ & $(0.227)$ & $(0.394)$ & $(0.632)$ & $(0.227)$ & $(0.382)$ \\
\hline \multirow[t]{2}{*}{ Education } & 1.843 & $17.273^{*}$ & 3.465 & 3.122 & $17.273^{*}$ & 2.035 \\
\hline & $(11.002)$ & (9.188) & $(11.847)$ & $(10.589)$ & (9.188) & $(0.382)$ \\
\hline \multirow[t]{2}{*}{ Urbanization } & -0.163 & -0.344 & $0.683^{* *}$ & -0.111 & -0.344 & $0.673^{* *}$ \\
\hline & $(0.246)$ & $(0.229)$ & $(0.340)$ & $(0.244)$ & $(0.229)$ & $(0.336)$ \\
\hline \multirow[t]{2}{*}{ Government expenditure } & 0.205 & $-0.538 * * *$ & -0.092 & 0.266 & $-0.538 * * *$ & -0.153 \\
\hline & $(0.322)$ & $(0.107)$ & $(0.240)$ & $(0.328)$ & $(0.107)$ & $(0.242)$ \\
\hline \multirow[t]{2}{*}{ Inflation } & 0.001 & 0.096 & 0.020 & 0.011 & 0.096 & 0.017 \\
\hline & $(0.037)$ & $(0.063)$ & $(0.047)$ & $(0.036)$ & $(0.063)$ & $(0.042)$ \\
\hline \multirow[t]{2}{*}{ Trade over GDP } & -0.016 & 0.012 & $-0.063^{* * *}$ & -0.015 & 0.012 & $-0.067 * * *$ \\
\hline & $(0.043)$ & $(0.024)$ & $(0.022)$ & $(0.043)$ & $(0.024)$ & $(0.022)$ \\
\hline \multirow{2}{*}{$\begin{array}{l}\text { Domestic credit to } \\
\text { private sector }\end{array}$} & $-0.025^{*}$ & $-0.008^{*}$ & $-0.029 *$ & $-0.026^{* *}$ & $-0.008^{*}$ & $-0.029 * *$ \\
\hline & $(0.013)$ & $(0.005)$ & $(0.015)$ & $(0.013)$ & $(0.005)$ & $(0.014)$ \\
\hline \multirow[t]{2}{*}{ Stocks traded over GDP } & -0.003 & $-0.005^{*}$ & -0.004 & -0.003 & $-0.005^{*}$ & -0.003 \\
\hline & $(0.006)$ & $(0.003)$ & (0.004) & $(0.006)$ & $(0.003)$ & $(0.004)$ \\
\hline Number of observations & 191 & 132 & 184 & 190 & 132 & 183 \\
\hline Scale Parameter & 1.990 & 0.330 & 1.446 & 1.963 & 0.330 & 1.400 \\
\hline Number of countries & 21 & 20 & 19 & 21 & 20 & 19 \\
\hline
\end{tabular}

Note. ${ }^{* * *} \mathrm{p}<0.01,{ }^{* *} \mathrm{p}<0.05,{ }^{*} \mathrm{p}<0.1$. GEE with Gaussian family and identity link. Country and year FEs are included in estimation, but coefficients are omitted from this table. Standard errors in parentheses are clustered at the country level. + indicates convergence is not achieved, and the correlation matrix is set just inside the minimum boundary for a definite correlation matrix according to the Stata xtgee routine.

We also split the sample based on the 2008 financial crisis, with 1996-2007 (Table A12) tested independently from 2008-2014 (Table A13). In the pre-crisis sample, R\&D spending has no relationship with any of the growth proxies, while its interaction with macroprudential policy is only significantly (and negatively) linked to per capita GDP growth. The post-crisis sample more closely resembles the overall results, with $\mathrm{R} \& \mathrm{D}$ spending again positively associated with gross capital formation, while the R\&D-macroprudential policy interaction is only significantly and negatively linked to capital formation when Portugal 2013 is included in the sample. In contrast 
with the full-sample results, the macroprudential policy index itself is positively and significantly linked to both per capita GDP growth and capital formation. This may reflect the greater use of macroprudential tools in response to the crisis (split-sample descriptive figures are presented in Tables A14 and A15), as well as wider variation in per capita GDP growth, despite a much lower mean. However, the macroprudential policy index and per capita GDP growth in the post-crisis sample are only weakly correlated, with a correlation coefficient of 0.204 .

\section{Discussion}

To summarize our results, we find robust evidence linking R\&D spending in the financial sector positively to gross capital formation, but not to per capita GDP growth or new firm density. Taken together, we find these results to provide an informative portrait of the relationship between financial innovation in a general sense and economic growth. There is no evidence indicating the existence of a net-negative relationship between financial innovation and economic growth, challenging the stigma associated with the growth effects of financial innovation. Given the role in financial innovation in optimizing the intermediation process, it is only natural that our broad innovation measure is linked to capital formation, although the results appear to be driven by innovation activities in the post-2008 financial-crisis period (Table A13). This discrepancy in pre- vs post-2008 crisis is likely reflective of the underlying function of the innovations which were more biased towards consumer credit pre-crisis. While a relationship might have been expected with both per capita GDP growth and firm formation, there are plausible reasons for the lack of effect in both cases. With respect to per capita GDP growth, intermediation improvements precede real-economy growth, although financial innovation itself is also likely to have an indirect effect through growth in capital formation. However, our null result with respect to the direct effect corroborates Beck et al.'s (2016), which also rely on 3-year lags and 5-year overlapping averages.

Likewise, the lack of direct influence on new firm density might also be expected. While financial innovation can drive firm formation through the financing of new firms or through spill-over effects and knowledge transfers, evidence from studies focusing on less broad-based aspects of innovation generate contradictory results. For example, while research on venture capital finds a strong positive link to firm formation (Urbano and Aparicio, 2016; Lerner and Tufano, 2011; Samila and Sorenson, 2011), as would be expected, securitization is negatively associated with firm formation (Bertay et al., 2017). While R\&D spending itself encompasses both of these types of innovation, it captures financial developments with a wide range of functional purposes, eroding the net effect on firm formation. 


\section{Figure 3 - Macroprudential Policy and Financial Innovation}
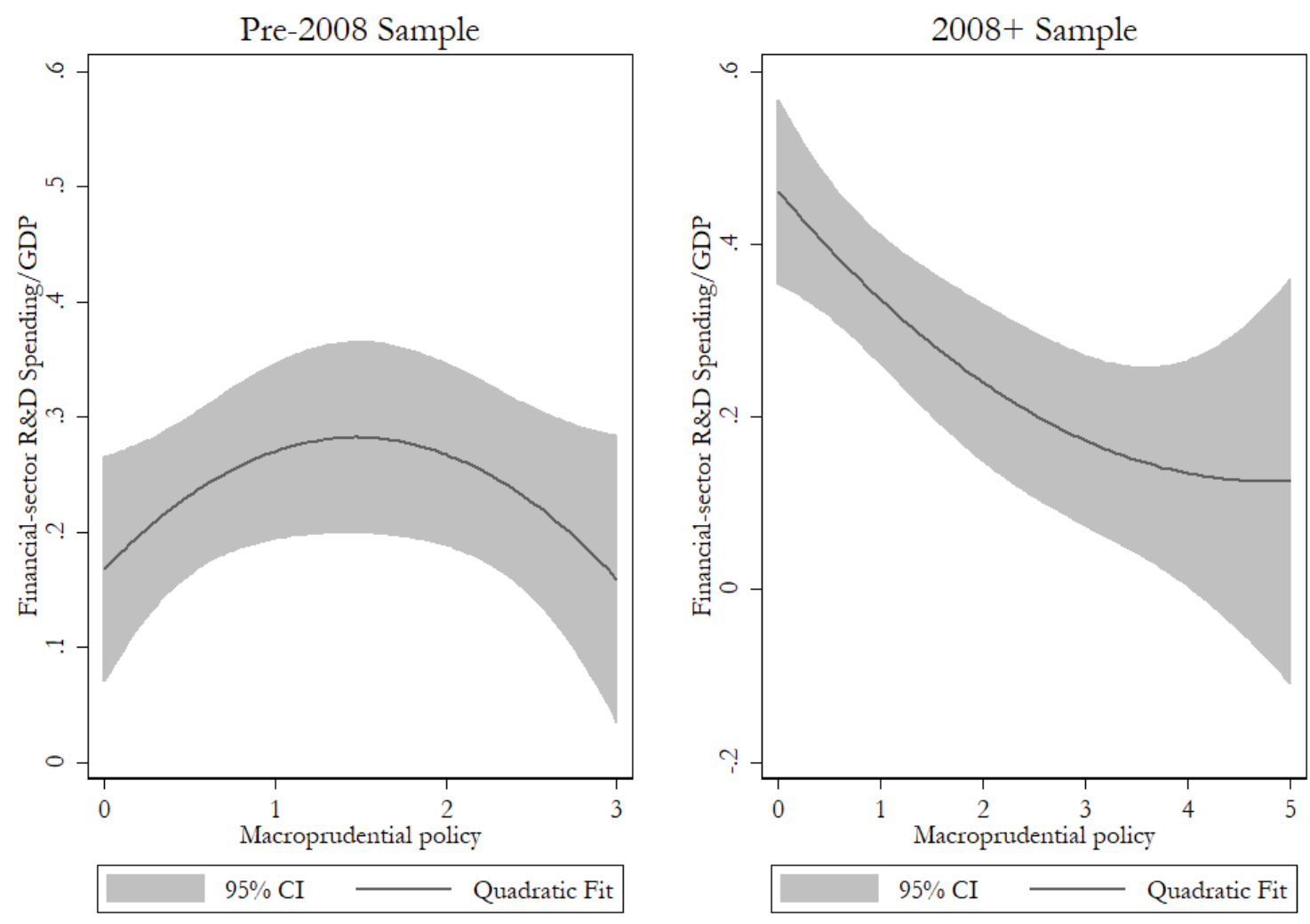

With respect to macroprudential policy, the significance of the effect on the relationship between financial innovation and economic growth is dependent on model specification and sample characteristics. Across all models, while significance may vary, the macroprudential policy's coefficient is positive, while that of its interaction with $\mathrm{R} \& \mathrm{D}$ spending is negative. In our baseline model, the significance of the macroprudential-policy and R\&D spending interaction on capital formation is effectively driven by the economic conditions in Portugal in 2013. Our robustness tests in the appendix also point to an additional factor in estimating the effects of macroprudential policy: differences before and after the 2008 financial crisis. In the post-crisis panel (Table A13), macroprudential policy is positively and significantly linked to both per capita GDP growth and gross capital formation; this is not the case for the pre-crisis panel (Table A12). Despite differences in the pre- and post-crisis regulatory environments, use of macroprudential policy itself does not appear to be driving financial innovation or its relationship with the measures of economic growth. ${ }^{4}$ Figure 3 illustrates this: prior to the crisis, R\&D spending peaks at low levels of macroprudential-policy implementation, while it is far more intensive in

\footnotetext{
${ }^{4}$ The correlation coefficient for this period is -0.282 , compared to 0.015 in the pre-2008 period.
} 
environments without macroprudential policy in the years following the crisis. The patterns here clearly reflect the distribution of R\&D-spending points in Figures 1 and 2.

We illustrate this further by dividing the macroprudential policy index into two groups in Figure 4. Where high levels of macroprudential policy characterize the regulatory environment, there appears to be a ceiling effect on financial-sector R\&D spending, likely to be occurring primarily through loan-to-value limits and reserve ratios.

Figure 4. R\&D spending in the financial sector and capital formation, as a function of high (index $=3,4,5$ ) and low (index $=0,1,2$ ) macro prudential policy index.

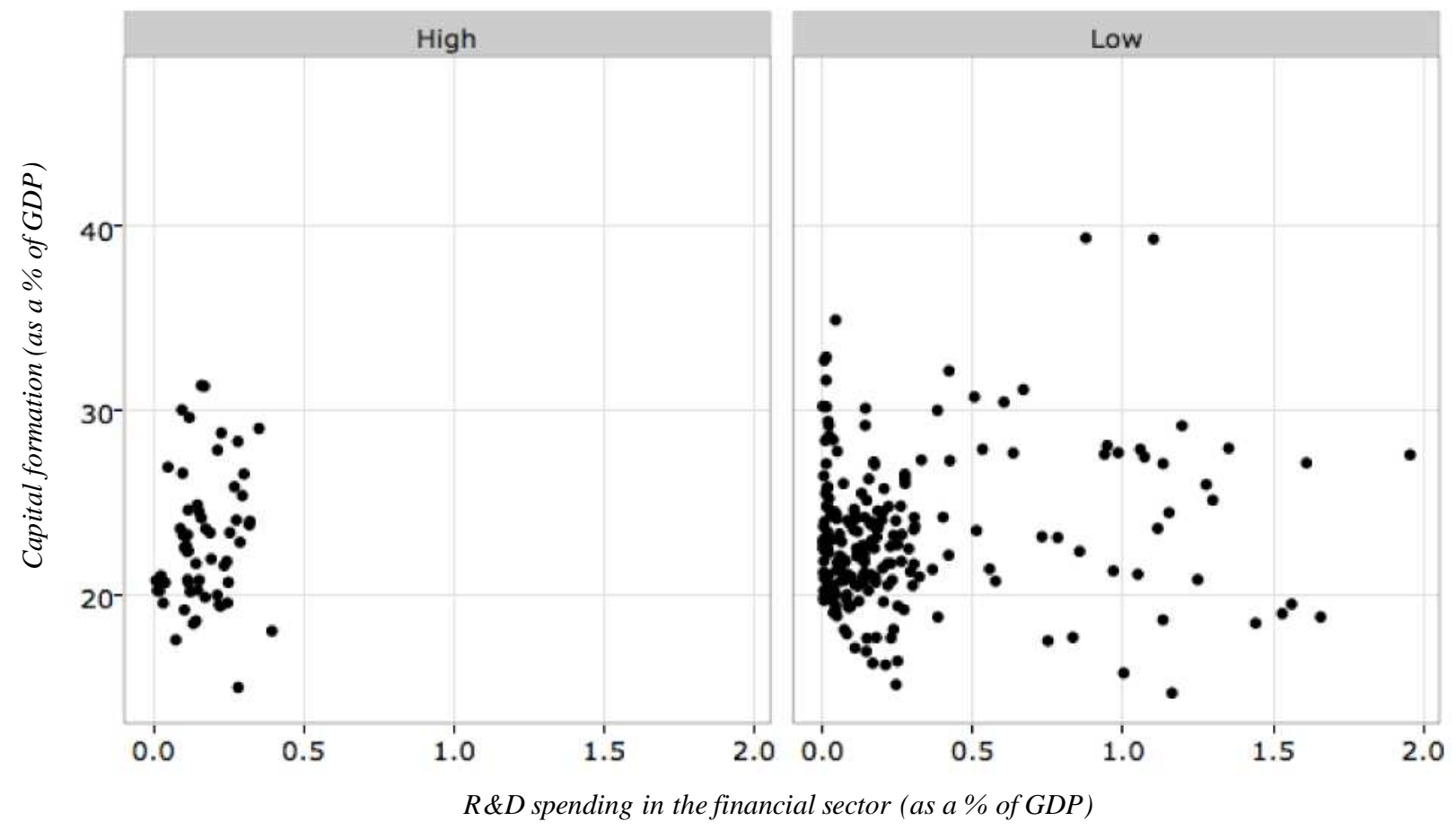

This effect appears to be the result of post-crisis rules in several countries requiring financial institutions, particularly issuers of debt and securitization products, to have a 'skin in the game', making them maintain on their balance sheet an increased amount of their loans. This, in turn, reduces firms' abilities to spend on financial innovation.

Finally, it is important to note that, while we analyze the effects of aggregate financial innovation, this is not evidence that regulation-induced financial innovation positively influences economic growth. We do not assess the sources of innovation; this requires a more disaggregated approach to data with respect to both financial innovation and macroprudential measures.

\section{Conclusions and Policy Implications}


Through the use of financial-sector R\&D spending, our study provides useful insight to the net relationship between financial innovation and economic and growth, complementing those presented by Beck et al. (2017). While we find a positive effect of financial innovation on gross capital formation, there is no relationship with per capita GDP growth or new firm density. These results largely support our expectation that innovation improves intermediation. We also assess the influence of macroprudential policy on this relationship and find little evidence that macroprudential policy diminishes financial innovation's effect on capital formation. However, while macroprudential policy itself may be positively related to per capita GDP growth, its interactive effect here is to reduce any potential influence of financial innovation.

This support for the positive effect of financial innovation on economic growth through capital formation lends useful insight to policy makers. At the aggregate level, financial innovation promotes economic growth, although we echo other scholars in arguing that a functional approach to regulation is necessary to promote beneficial innovations while constraining harmful innovations. As first highlighted by Merton (1992), the functions of financial institutions, contrary to their structure, are robustly constant. To date, however, policy-makers have taken an "institution" based approach to policy-making. In other words, this approach focuses on the architectural structure of a financial firm, rather than the functional purpose of the innovation, to determine its policy configuration. Merton (1992), Schwarcz (2014), and Ross (2016), advocate a policy approach for financial innovation that is focused on its functional outcome.

An innovation-targeted approach to regulation is likely to become all the more necessary as technological advances have spurred a wave of innovative and heterogeneous start-ups in the fintech movement, which could lead to increased institutional variability within the financial sector. As a starting point, innovations that improve the intermediation process through more effective screening, matching, and capital distribution, can be looked upon favorably by policy makers, while those that disguise risk or information, or obfuscate the intermediation process should be avoided. Similarly, innovations that target enterprise growth and investment are likely to contribute to economic growth. In both cases, misguided regulations have potential to hinder growth, and policy makers face a difficult challenge in distinguishing truly beneficial innovations from those disguised to appear as them. 


\section{Works Cited:}

Abramovitz, M. 1956. Research and Output Trends in the United States since 1870. National Bureau of Economic Research, Occasional Paper 52, pp. 1-23.

ANBERD. 2016. Analytical Business Enterprise Research and Development database. OECD.

Arcand, J.L., Berkes, E. and Panizza, U. 2012. Too much finance?. IMF Working Paper No.12/161.

Calomiris, C.W. 2009. Financial Innovation, Regulation, and Reform. Cato Journal, 29(1), pp.6591.

Barnett-Hart, A. 2009. The Story of the CDO Market Meltdown: An Empirical Analysis. BA. Harvard University.

Basto, R.B. 2013. A Macro-Prudential Policy for Financial Stability. Banco de Portugal, Economic Reseach Department, Financial Stability Report, pp.73-86.

BBC News. 2016. Portugal reaches deal on EU and IMF bail-out - BBC News. [online] Available at: http://www.bbc.com/news/business-13275470 [Accessed 11 Aug. 2016].

Beck, T., Chen, T., Lin, C. and Song, F. 2016. Financial Innovation: The Bright and the Dark Sides. Journal of Banking and Finance, 72(1): 28-51.

Bertay, A., Gong, D. and Wagner, W. 2016. Securitization and economic activity: The credit composition channel. Journal of Financial Stability.

Board of Governors of the Federal Reserve System. 2011. Liquidity and Reserve Requirements in Brazil. International Finance Discussion Papers.

Büyükkarabacak, B. and Valev, N. 2010. The role of household and business credit in banking crises. Journal of Banking and Finance, 346, pp.1247-1256.

Carbo-Valverde, S., Degryse, H. and Rodríguez-Fernández, F. 2015. The impact of securitization on credit rationing: Empirical evidence. Journal of Financial Stability, 20, pp.36-50.

Cerutti, E., Claessens, S. and Laeven, L. 2015. The use and effectiveness of macroprudential policies: New evidence. Journal of Financial Stability.

Chou, Y. 2007. Modeling Financial Innovation and Economic Growth: Why the Financial Sector Matters to the Real Economy. The Journal of Economic Education, 381, pp.78-90.

Cook, Q.T. and Duffield, J.G. 1979. Money market mutual funds: A reaction to government Regulations or a lasting financial innovation?. FRB Richmond Economic Review, 65(4), pp.15-31.

Dwyer, P. 2011. Financial Innovation and the Financial Crisis of 2007-2008. Federal Reserve Bank of Atlanta.

Fagerberg, J. 1997. Competitiveness, scale and R\&D. In Fagerberg, J., Hansson, P., Lundberg, L. and Melchior, A. eds. Technology and international trade. Cheltenham: Edward Elgar.

Frame, W. Scott and White, Lawrence J. 2014. Technological Change, Financial Innovation, and Diffusion in Banking. NYU Working Paper No. 2451/33549.

Galati, G. and Moessner, R. 2013. Macroprudential Policy - a Literature Review. Journal of Economic Surveys, 27(5), pp.846-878

Gauthier, C., Lehar, A. and Souissi, M. 2010. Macroprudential regulation and systemic capital requirements. Bank of Canada, Working Paper 2010-4. 
Gauthier, C., Gravelle, T., Liu, X. and Souissi, M. 2011. What matters in determining capital surcharges for systemically important financial institutions? Bank of Canada, Discussion Paper 2011-9.

International Monetary Fund. 2011. Global financial stability report. Available at http://www.imf.org/External/Pubs/FT/GFSR/2011/02/index.htm last accessed 21 June 2016.

Janicko, M. 2015. Mainstream Versus Heterodox View on Financial Innovation. International Journal of Economic Sciences, 4(1), pp.1-74.

Jorda, O., Schularick, M. and Taylor, A. 2012. When Credit Bites Back: Leverage, Business Cycles and Crises. Federal Reserve Bank of San Francisco, Working Paper Series, 201127.

Keys, B., Mukherjee, T., Seru, A. and Vig, V. 2010. Did Securitization Lead to Lax Screening? Evidence from Subprime Loans. Quarterly Journal of Economics, 1251, pp.307-362.

King, R. and Levine, R. 1993. Finance and Growth: Schumpeter Might Be Right. Quarterly Journal of Economics, 1083, pp.717-737.

Kortum, S. and Lerner, J. 2000. Assessing the Contribution of Venture Capital to Innovation. RAND Joumal of Economics, 314, p.674.

Laeven, L., Levine, R. and Michalopoulos, S. 2015. Financial innovation and endogenous growth. Journal of Financial Intermediation, 241, pp.1-24.

Laeven, L. and Valencia, F. 2015. Systemic banking crises: A new database. IMF working paper, $\mathrm{WP} / 08 / 224$.

Lerner, J. and Tufano, P. 2011. The Consequences of Financial Innovation: A Counterfactual Research Agenda. Annual Review of Financial Economics, 31, pp.41-85.

Levine, R. 1997. Financial Development and Economic Growth: Views and Agenda. Journal of Economic Literature, pp.688-726.

Lima, J. (2016). Portugal Seeks Market Access With \$5 Billion Bond Exchange - Bloomberg. [online] Bloomberg.com. Available at: http://www.bloomberg.com/news/articles/2012 10-03/portugal-seeks-market-access-with-5-billion-bond-exchange [Accessed 10 Aug. 2016].

Lumpkin, S. 2010. Regulatory issues related to financial innovation. OECD Journal: Financial Market Trends, 20092, pp.1-31.

Márquez-Ramos, L. and Martínez-Zarzoso, I. 2010. The Effect of Technological Innovation on International Trade. A Nonlinear Approach. Economics E-Journal, 42010-11, p.1.

Merton, R. 1992. Financial Innovation and Economic Performance. Journal of Applied Corporate Finance, 44, pp.12-22.

Merton, R. 1995. Financial innovation and the management and regulation of financial institutions. Journal of Banking and Finance, 193-4, pp.461-481.

Michalak, T. and Uhde, A. 2012. Credit risk securitization and bank soundness in Europe. Quarterly Review of Economics and Finance, 523, pp.272-285.

Miller, M. 1986. Financial Innovation: The Last Twenty Years and the Next. Journal of Financial and Quantitative Analysis, 214, p.459.

Morales, M. 2003. Financial Intermediation in a Model of Growth Through Creative Destruction. Macroeconomic Dynamics, 7(3), pp. 363-393. 
Nadauld, T. and Weisbach, M. 2012. Did securitization affect the cost of corporate debt?. Journal of Financial Economics, 1052, pp.332-352.

Posner, M.V. 1961. International trade and technical change. Oxford Economic Papers 13, 323341

Rajan, R. 2005. Has Financial Development Made the World Riskier?, Proceedings of the Jackson Hole Conference organized by the Kansas City Federal Reserve.

Ross, V. 2016. Financial Innovation: towards a balanced regulatory response. In: How Imminent is the real Fintech Revolution. London.

Samila, S. and Sorenson, O. 2011. Venture Capital, Entrepreneurship, and Economic Growth. Review of Economics and Statistics, 931, pp.338-349.

Schumpeter, J.A. 1911. The Theory of Economic Development Cambridge, MA: Harvard University Press.

Schumpeter, J. A. 1950. Capitalism, Socialism and Democracy Harper and Brothers, New York

Schwarcz, S. 2014. The Functional Regulation of Finance. SSRN Electronic Journal.

Segoviano, M., Jones, B,. Lindner, P., and Blankenheim, J. 2013. Securitization: Lessons Learned and the Road Ahead. IMF Working Papers, 13255.

Shadow Financial Regulatory Committees of Asia, Australia-New Zealand, Europe, Japan, Latin America, and the United States, 2009. Making Securitization Work for Financial Stability and Economic Growth. Statement 20. Santiago.

Shan, S., Tang, D. and Yan, H. 2016. Regulation-Induced Financial Innovation: The Case of Credit Default Swaps and Bank Capital. SSRN Electronic Journal.

Silber, L.W. 1983. The Process of Financial Innovation. American Economic Review, 73(2), pp. 8995.

Tufano, P. 1989. Financial innovation and first-mover advantages. Journal of Financial Economics, 252, pp.213-240.

Tufano, P. 2003. Financial Innovation. In: G. Constantinides, R. Stulz and M. Harris, ed., The Handbook of the Economics of Finance, 1st ed. Corporate Finance, pp.307-335.

Urbano, D. and Aparicio, S. 2016. Entrepreneurship capital types and economic growth: International evidence. Technological Forecasting and Social Change, 102, pp.34-44.

Wall, L.D. 2014. Two Drivers of Financial Innovation. Federal Reserve Bank of Atlanta, 2014. Notes from the vault.

World Development Indicators, The World Bank. Available at: http://data.worldbank.org/data catalog/world-development-indicators [Accessed 10 June. 2016].

Yorulmazer, T. 2012. Has Financial Innovation Made the World Riskier? CDS, Regulatory Arbitrage and Systemic Risk. SSRN Electronic Journal. 